3. Needlestick Safety and Prevention Act of 2000. Pub.L No. 106-430, 114 Stat. 1901. 11-62000 .

Janine Jagger, MPH, PhD University of Virginia School of Medicine Charlottesville, Virginia

\section{Incidence of Nosocomial Infection in a Brand-new Hospital}

To the Editor:

Continuous hospitalwide surveillance for nosocomial infection (NI) was begun on the opening of a new 250-bed community hospital in Alzira, Spain. We report the results of the first year of surveillance.

The hospital has an intensive care unit with 12 beds. Most of the rooms in the inpatient ward are single. The hospital opened on January 1,1999. During the first month, a multidisciplinary team was formed with the aim of performing surveillance and preventing infections. It included specialists in epidemiology, microbiology, and infectious diseases.

A cross-sectional study of NI was done in February 1999. Continuous surveillance for NI was performed daily during the rest of the year. Data on NI before the cross-sectional study were obtained from the microbiology department records and computerized medical notes. The cumulative incidence of $\mathrm{NI}$ and incidence densities per 1,000 patientdays were calculated by department. All isolated microorganisms were discussed daily by the multidisciplinary team to confirm the presence of NI following the Center for Disease Control (CDC) criteria. ${ }^{1,2}$ The incidence of isolated microorganisms was evaluated by infection site.

The prevalence of NI in the initial cross-sectional survey was $6.5 \%$ (95\% confidence interval $\left[\mathrm{CI}_{95}\right], 3.0$ to $10.0)$. Sites of infection included surgical (2.7\%; $\mathrm{CI}_{95}, 0.4$ to 5.0$)$, lower respiratory tract $\left(1.0 \% ; \mathrm{CI}_{95}, 0.0\right.$ to 2.4$)$, and soft tissue (1.0\%; $\mathrm{CI}_{95}, 0.0$ to 2.4). Of 12,766 patients admitted during the study period, 371 met CDC criteria for NI (2.9 per 100 admissions). The intensive care unit had the highest cumulative incidence (16.6 per 100 admissions), followed by general surgery (4.0 per 100 admissions) and plastic surgery (3.0 per 100 admissions) (Table). The incidence rate in the intensive care unit was 4.2 per 100 patient-days. However, it should be noted that two-thirds of NIs occurred outside the intensive care unit.

By infection sites, cumulative incidence rates per 100 admissions were $0.3 \%$ for urinary tract, $0.9 \%$ for surgical wound, $0.5 \%$ for primary bacteremia, $0.1 \%$ for soft tissue, and $0.3 \%$ for pneumonia.
Methicillin-resistant Staphylococcus aureus accounted for $40 \%$ of nosocomial $S$. aureus infection $\left(\mathrm{CI}_{95}\right.$, 25.7 to 54.3 ), with an incidence density of 0.3 per 1,000 patient-days $\left(\mathrm{CI}_{95}\right.$, 0.24 to 0.30 ). Escherichia coli accounted for $33.3 \%$ and Pseudomonas aeruginosa $25 \%$ of urinary tract infections. Among surgical-site infections, $E$. coli was identified in $14.2 \%$, $P$ aeruginosa in $13.5 \%$, and $S$. aureus in $6 \%$. . a aeruginosa was identified in $23.7 \%$ and $S$. aureus in $21 \%$ of lower respiratory tract infections. $P$. aeruginosa and $S$. aureus were isolated in $8.3 \%$ of pneumonias. Coagulase-negative staphylococci were isolated in $33.8 \%$, S. epidermidis in $22.5 \%$, and $P$. aeruginosa in $3.2 \%$ of primary bacteremias.

The prevalence of NI in the initial cross-sectional study was lower than the prevalence published by the EPINE study (Spanish Prevalence Survey of NI). ${ }^{3}$ Of note, surgical-site infection was the most frequent NI observed (32\%), with highest rates in the intensive care unit (2.7 per 100 admissions), general surgery (2.4 per 100 admissions), and or thopedics (1.9 per 100 admissions).

Primary bacteremia rates were higher than those previously reported by the National Nosocomial Infections Surveillance system. ${ }^{4}$ Nosocomial pneumonia rates were lower than those reported by Barsic et al., ${ }^{5}$ but lower respiratory tract infections were

TABLE

Cumulative InCidence of Nosocomial Infection by SERvice and INFection Location

\begin{tabular}{|c|c|c|c|c|c|c|c|c|c|c|}
\hline \multirow[b]{2}{*}{ Service } & \multirow[b]{2}{*}{$\begin{array}{l}\text { Total No. } \\
\text { Admltted }\end{array}$} & \multirow[b]{2}{*}{$\begin{array}{l}\text { Total No. } \\
\text { Infected }\end{array}$} & \multirow[b]{2}{*}{$\begin{array}{c}\text { Incidence per } 100 \\
\text { Admitted }\left(\mathrm{Cl}_{98}\right)\end{array}$} & \multicolumn{7}{|c|}{ Incldence per 100 Admissions by Site } \\
\hline & & & & ss & PNE & BS & UT & $\mathbf{L R}$ & ST & $\begin{array}{l}\text { Miscella- } \\
\text { neous* }\end{array}$ \\
\hline General surgery & 1,765 & 71 & $4.0 \quad(3.0$ to 4.9$)$ & 2.4 & 0.3 & 0.5 & 0.4 & - & - & 0.2 \\
\hline Orthopedics & 1,234 & 33 & $2.5 \quad(1.7$ to 3.3$)$ & 1.9 & 0.2 & - & 0.1 & - & - & 0.2 \\
\hline Pediatrics & 906 & 7 & $0.7 \quad(0.2$ to 1.2$)$ & 0.1 & - & 0.1 & 0.1 & - & 0.2 & 0.2 \\
\hline Neurosurgery & 267 & 6 & $2.2 \quad(0.5$ to 3.9$)$ & - & 1.1 & - & 0.7 & - & - & 0.3 \\
\hline Medicine & 4,967 & 74 & 1.4 (1.1 to 1.7$)$ & 0.1 & 0.3 & 1.3 & 0.2 & - & - & 0.2 \\
\hline Intensive care unit & 727 & 121 & 16.6 (13.9 to 19.3$)$ & 2.7 & 1.5 & 4.5 & 1.7 & 3.7 & 0.5 & 1.7 \\
\hline Gynecology & 705 & 12 & $1.6 \quad(0.7$ to 2.5$)$ & 1.1 & - & - & 0.2 & - & - & 0.2 \\
\hline Oncology & 333 & 10 & 2.7 (1.0 to 4.4$)$ & 0.3 & 0.3 & 0.9 & 0.6 & - & 0.3 & 0.6 \\
\hline ORL & 702 & 8 & $1.1 \quad(0.4$ to 1.8$)$ & 0.4 & 0.2 & 0.1 & - & - & - & 0.2 \\
\hline Plastic surgery & 132 & 4 & $3 \quad(0.1$ to 5.9$)$ & 1.5 & - & - & - & - & 0.7 & 0.7 \\
\hline Thoracic surgery & 151 & 2 & $1.3 \quad(0$ to 3.1$)$ & 1.3 & - & - & - & - & - & - \\
\hline Vascular surgery & 237 & 4 & $1.6 \quad(0.1$ to 3.1$)$ & 1.2 & - & - & - & - & - & 0.4 \\
\hline Urology & 640 & 19 & 2.9 (1.6 to 4.2$)$ & 0.7 & 0.1 & 0.6 & 0.6 & - & 0.1 & 0.6 \\
\hline Total & 12,766 & 371 & $2.9 \quad(2.6$ to 3.1$)$ & 118 & 46 & 64 & 48 & 28 & 14 & 53 \\
\hline
\end{tabular}

$\mathrm{CI}_{95}$ * 95\% confidence interval; $\mathrm{SS}$ - surgical site; $\mathrm{PNE}$ = pneumonia; $\mathrm{BS}$ = bloodstream; UT = urinary tract; $\mathrm{LR}=$ lower respiratory tract; $\mathrm{ST}$ - soft tissue; $\mathrm{ORL}=$ otorhinolaryngology. *Occasional infections involving the gastrointestinal tract, ears, genitals, and oropharynx. 
more frequent (3.7 per 100 admissions) and may have represented misdiagnosed nosocomial pneumonias. The distribution of microbes causing NI in this new hospital was similar to that in an older hospital. This database will be used to establish endemic NI rates and to plan interventions to lower these rates.

\section{REFERENCES}

1. Garner JS, Emori WR, Horan TC, Hughes JM. CDC definitions for nosocomial infec- tions. Am J Infect Control 1988;16:128140.

2. Horan TC, Gaynes RP, Martone WJ, Jarvis WR, Emori TG. CDC definitions of nosocomial surgical site infections, 1992: a modification of $\mathrm{CDC}$ definitions of surgical wound infections. Infect Control Hosp Epidemiol 1992;13:606-608.

3. Vaque J, Rossello J, Arribas JL. Prevalence of nosocomial infections in Spain: EPINE study 1990-1997. J Hosp Infect 1999; 43(suppl):S105-S111.

4. National Nosocomial Infections Surveillance System. Nosocomial infection rates for inter-hospital comparison: limitations and possible solutions. Infect Control
Hosp Epidemiol 1991;12:609-621.

5. Barsic B, Beus I, Marton E, Himbele J, Klinar I. Nosocomial infections in critically ill infectious disease patients: results of a 7-year focal surveillance. Infection 1999;27:16-22.

Ricardo Bou, MD, PhD

Pilar Ramos, MD

Miguel Peris, MD

Miguel Salavert, MD

Angel Aguilar, MD

Javier Colomina, $\mathbf{P h D}$

Hospital de la Ribera

Alzira, Valencia, Spain 